$7^{\circ}$ Simposio Internacional de Investigación Multidisciplinaria / Ciencia y Tecnología 7th Internationalm Symposium on Multidisciplinary Research / Sciences and Technology

\section{CT-15 Arquitectura Tecnológica de un Sistema Inteligente de Tutorías}

\author{
Technological Architecture of an Intelligent Tutoring System
}

Selene García*, José A. Gómez, María L. Sánchez

Instituto Tecnológico Superior de Las Choapas (ITSCH), Las Choapas México.

*Autor al que se dirige la correspondencia: sgarnie@hotmail.com

\title{
Resumen
}

$\mathrm{E}$ 1 objetivo de esta investigación es desarrollar una arquitectura tecnológica de un sistema inteligente de tutorías para el mejoramiento del programa de tutorías del ITSCH mediante técnicas de Inteligencia Artificial. Para cumplir con el objetivo planteado se realizó un estudio de caso en donde se analizaron los indicadores de deserción, reprobación, baja temporal y eficiencia terminal en el ITSCH, en el caso de estudio también se evaluaron las percepciones actuales tanto en los tutores como en los alumnos tutorados respecto al estado actual del Programa Nacional de Tutorías, así como diversas percepciones futuras. Se identificaron diversos desafíos y se propone la arquitectura de un sistema inteligente de tutorías para determinar los perfiles de los alumnos a través de redes neuronales. Se realizó una simulación de una red neuronal multicapa en el software Matlab basándose en la Prueba $16 \mathrm{PF}$. En los resultados preliminares se determina que es factible asignar actividades a los alumnos tutorados utilizando esta técnica de inteligencia artificial.

Palabras claves: Sistema Inteligente, tutoría inteligente, tutoría, arquitectura tecnológica, inteligencia artificial

\begin{abstract}
$\mathrm{T}$

The objective of this research is to develop a technological architecture of an intelligent system of tutorials for the improvement of the tutorial program of the ITSCH through techniques of Artificial Intelligence. In order to comply with the stated objective, a case study was carried out in which the indicators of desertion, disapproval, temporary leave and terminal efficiency in the ITSCH were analyzed, in the case study the current perceptions were evaluated in both the tutors and the tutored students regarding the current state of the National Tutoring Program, as well as various future perceptions. Several challenges were identified and an architecture of an intelligent tutoring system is proposed to determine student profiles through neural networks. We performed a simulation of a multilayer neural network in the Matlab Software based on Test $16 \mathrm{PF}$, in the preliminary results it is determined that it is feasible to assign activities to the students tutored using this technique of artificial intelligence.
\end{abstract}

Keywords: Intelligent System, intelligent tutoring, tutoring, technological architecture, artificial intelligence 